\title{
Grammatical Errors Analysis in the Thesis Abstracts Made by the Students of Borneo University Tarakan
}

\author{
Syarifa Rafiqa ${ }^{1, *}$ Nofvia De Vega ${ }^{2}$ \\ ${ }^{1}$ Fakultas Keguruan dan Ilmu Pendidikan, Universitas Borneo Tarakan \\ ${ }^{2}$ Fakultas Keguruan dan Ilmu Pendidikan, Universitas Borneo Tarakan \\ *Corresponding author. Email: rafiqa@borneo.ac.id
}

\begin{abstract}
This research aimed to identify and describe the common types of grammatical errors and the sources of errors made by the students in thesis abstracts. The research design in this research was descriptive qualitative, the respondent was a student of Borneo University Tarakan who graduated in 2016 and had officially compiled their thesis to the library of Borneo University Tarakan. There were 247 thesis abstracts to be used as a sample. The result showed that 1079 total errors were found in the thesis abstract made by students. The researcher took ten samples of the source of errors, and those samples were the common errors taken from 4 categories based on the Taxonomy of Errors. There were developmental errors, interlingual errors, ambiguous errors, and other errors.
\end{abstract}

Keywords: Thesis Abstract, Language Learning, Writing Skill

\section{INTRODUCTION}

According to Hornby [1], a thesis is a long piece of writing completed by a student as part of a university degree based on their research. It is known better as the student's final project, usually in the form of scientific works or research papers for a bachelor's degree. In a thesis, there is a small yet important part, namely abstract. The abstract is a stand-alone text presented at the beginning of a scientific paper (the objective, methodology, result, and conclusion of the research), and it is considered the first impression and expectation the reader will get about the whole paper. It is a condensed version of the whole dissertation or thesis [2], [3]. Therefore, the thesis abstract is more like a mini-thesis or short version of the thesis.

It is not a big deal for English department students. However, for the students from the other faculties and departments, in Borneo University Tarakan, it is difficult to be done since the English language is not their majors. From the small observation that the researcher has done before composing this research, the researcher found that most of the economy department's thesis abstracts, primary school teacher department, and Agriculture department are poorly written. They find that making good writing in a foreign language is a total struggle for them since they have to translate their ideas from their mother tongue into the target language. That is why they tend to make mistakes and commit numerous errors. It is a real problem that ought to be investigated.

Committing errors are not always bad in language learning because it results from learning activity, and it is proof that learning activity keeps going. This study's researcher had done a preliminary study in the library of Borneo University of Tarakan on the 4th floor on March 27th, 2017, in students' thesis abstracts. The researcher found that the students were still found to commit errors in their abstracts, such as an article, plurals, verb, etc. These results made the researcher believed that other students committed the same errors in making the thesis abstract.

Based on the problem above, a study of students' errors needs to be taken by the researcher to identify how far students committed errors in making the thesis abstract. Corder [4] [5] states that the study of the students' error will significantly contribute to second language acquisition because it helps students, teachers, and researchers understand the source of any committed errors to improve language competence by constructing correction techniques. Shortly, it is expected to help the 
students be more aware of their errors, reflecting their competencies. It also hopefully can give valuable information and data to the students on their errors. Therefore, this research is focused on grammatical errors committed by the students of Borneo University Tarakan.

\section{RESEARCH DESIGN}

The researcher has used a descriptive qualitative research design for two reasons. Firstly, this research design is appropriate to describe the types of errors and explain the result of the study easily understood. Secondly, descriptive qualitative research design has been used by many researchers, which can be used as references.

This research was in the Borneo University of Tarakan library by collecting the data to be analyzed. Meanwhile, the participants of the study in qualitative research, a person/individual who participates in a research study or someone from whom the data are collected is identified as research are the students of Borneo University of Tarakan who graduated in 2016 and had officially compiled their theses to the library of Borneo University Tarakan. The librarian stated that 900 theses were compiled by the Borneo University of Tarakan students in 2016. From those theses, the researcher has selected 225 theses abstracts as the research samples by using random sampling.

Since this research's sources data are thesis abstracts, which are in the form of writings or documents, the researcher was used the documentary study as the technique in collecting the data. First of all, the researcher was observed and collected the sources of the data. To get access to conduct the research and take the data are needed, the researcher was addressed permission letter to head of the Library of Borneo University Tarakan. After the researcher got the permission to take the data in the form of softcopies, it contained a name list of Borneo University students and their thesis abstracts from the library database. The researcher selected some of the thesis abstracts as the samples by using a simple random sampling technique. After that, the researcher analyzed the thesis abstracts' contents to find out the grammatical errors that occur and categorize them according to their possible sources. Those errors were validated to make them more reliable and valid.

\section{FINDING AND DISCUSSION}

\subsection{Finding}

In this section, the researcher described further the classification and categorization of errors. They can be explained as follows:

\subsubsection{Classification of Errors}

The researcher collected the Borneo University library data, the students' abstracts of teacher training and education faculty, Economic Faculty, and Fishery and Marine Science Faculty. In classifying the kind of errors in students' abstracts, the researcher used the Surface Strategy Taxonomy, one of the error taxonomies used to determine the kind of error in students' abstracts. Based on the data found, the grammatical errors which occurred in the students' sentences in abstracts were grouped into four types, they were 1) Omission Error, 2) Addition Error, 3) Misformation Error, 4) Missordering Error.

Table1. Detailed Description on Surface Strategy Taxonomy in Students; Abstracts

\begin{tabular}{|c|c|c|}
\hline Category & Example & Explanation \\
\hline Omission & $\begin{array}{l}\text { Assessment of } \\
\text { Agricultural Extension } \\
\text { Development Of } \\
\text { Agriculture In Kota } \\
\text { Tarakan would provide } \\
\text { troubleshooting } \\
\text { member farmer group } \\
\text { Sinar }\end{array}$ & $\begin{array}{l}\text { Missing of } \\
\text { Preposition on and } \\
\text { for in the sentences }\end{array}$ \\
\hline Addition & $\begin{array}{l}\text { The role of extension } \\
\text { officers in the } \\
\text { empowerment that is } \\
\text { helping farmers improve } \\
\text { welfare by enriching } \\
\text { knowledge }\end{array}$ & $\begin{array}{l}\text { inclusion of } \\
\text { preposition in the } \\
\text { sentence }\end{array}$ \\
\hline Misformation & $\begin{array}{l}\text { The role of extension } \\
\text { officers in the } \\
\text { empowerment that is } \\
\text { helping } \\
\text { farmers improve welfare } \\
\text { by enriching knowledge }\end{array}$ & $\begin{array}{l}\text { The missing of - } \\
\text { ing form (gerund) } \\
\text { empowering }\end{array}$ \\
\hline Misordering & $\begin{array}{l}\text { This research was } \\
\text { conducted in the South } \\
\text { (south nunukan) District } \\
\text { Nunukan, }\end{array}$ & $\begin{array}{l}\text { The sentence } \\
\text { above contains a } \\
\text { misordering error. } \\
\text { It is because of } \\
\text { mother tongue } \\
\text { interference while } \\
\text { translating a target } \\
\text { language from the } \\
\text { other language. }\end{array}$ \\
\hline
\end{tabular}

\subsubsection{Sub Categorization of Errors}

The four categories of error were classified into 18 subcategories. The researcher found 1079 total errors of Borneo University Tarakan. They were the errors in 
subcategories of verb be, verb, v.t, article, determiner, plural, singular, noun, adjective, conjunction, preposition, gerund, adverb, auxiliary, word order, word missing, spelling, and unnecessary. The detailed description was related to the distribution of subcategories of grammatical errors found in abstracts, including the student who committed the errors.

\subsubsection{Verb be}

Tabel 2 The Sample of Grammatical Error of Verb be

\begin{tabular}{|l|l|l|}
\hline Code & \multicolumn{1}{|c|}{$\begin{array}{c}\text { Erroneous of } \\
\text { Sentence }\end{array}$} & $\begin{array}{c}\text { The } \\
\text { suggestion of } \\
\text { Correct } \\
\text { Sentence }\end{array}$ \\
\hline A1 & $\begin{array}{l}\text { Bombay duck by the } \\
\text { people of Tarakan } \\
\text { used as raw material for } \\
\text { salted fish and crackers } \\
\text { made from fish. }\end{array}$ & $\begin{array}{l}\text { Bombay duck } \\
\text { by the people of } \\
\text { Tarakan is used } \\
\text { as raw material } \\
\text { for salted fish } \\
\text { and crackers } \\
\text { made from fish. }\end{array}$ \\
\hline
\end{tabular}

The grammatical error of the verb is found in the sentence above, which was omission errors. It had been found 41 error of omission, 10 error of addition, one error of misordering, and 33 error of misformation.

\subsubsection{Verb}

Tabel 3 The Sample of Grammatical Error of Verb

\begin{tabular}{|c|l|l|}
\hline Code & \multicolumn{1}{|c|}{$\begin{array}{c}\text { Erroneous of } \\
\text { Sentence }\end{array}$} & $\begin{array}{c}\text { The } \\
\text { suggestion of } \\
\text { Correct } \\
\text { Sentence }\end{array}$ \\
\hline A22 & $\begin{array}{l}\text { Empathy variable } \\
\text { significantly, }\end{array}$ & $\begin{array}{l}\text { Empathy } \\
\text { variable } \\
\text { significantly, } \\
\text { Positively effects on } \\
\text { costumers satisfaction. } \\
\text { positively } \\
\text { affects } \\
\text { costumers } \\
\text { satisfaction }\end{array}$ \\
\hline
\end{tabular}

The type of grammatical error of the verb found in the sentence above which was misformation errors. It found 1 error of omission, 0 error of addition, 0 error of misordering, and 7 error of misformation.

\subsubsection{Verb Tense}

Tabel 4 The Sample of Grammatical Error of Verb Tense

\begin{tabular}{|c|c|c|}
\hline Code & $\begin{array}{c}\text { Erroneous of } \\
\text { Sentence }\end{array}$ & $\begin{array}{c}\text { The suggestion of } \\
\text { Correct Sentence }\end{array}$ \\
\hline A6 & $\begin{array}{l}\text { contained on farmer I } \\
\text { who had the largest }\end{array}$ & $\begin{array}{l}\text { contained on farmer } \\
\text { I who has the largest }\end{array}$ \\
\hline
\end{tabular}

There was a misformation error from the sentence above, which was the "had" as a past tense. It had been found 20 error of omission, 1 error of addition, 1 error of misordering, and 27 error of misformation.

\subsubsection{Article}

Tabel 5 The Sample of Grammatical Error of Article

\begin{tabular}{|c|c|c|}
\hline Code & $\begin{array}{c}\text { Erroneous of } \\
\text { Sentence }\end{array}$ & $\begin{array}{l}\text { The suggestion of } \\
\text { Correct Sentence }\end{array}$ \\
\hline A12 & $\begin{array}{l}\text { Education levels } \\
\text { dominate primary } \\
\text { school education } \\
(40 \%) \text {, and the } \\
\text { number of family } \\
\text { members who } \\
\text { dominates is } \\
\text { number } 1-2 \\
\text { people }(56 \%)\end{array}$ & $\begin{array}{l}\text { Education levels } \\
\text { dominate the primary } \\
\text { school education } \\
(40 \%) \text {, and the number } \\
\text { of family members } \\
\text { who dominates is the } \\
\text { number of } 1-2 \text { people } \\
(56 \%)\end{array}$ \\
\hline
\end{tabular}

\subsubsection{Determiner}

Tabel 6 The Sample of Grammatical Error of Determiner

\begin{tabular}{|c|l|l|}
\hline Code & \multicolumn{1}{|c|}{$\begin{array}{c}\text { Erroneous of } \\
\text { Sentence }\end{array}$} & \multicolumn{1}{|c|}{$\begin{array}{l}\text { The suggestion of } \\
\text { Correct Sentence }\end{array}$} \\
\hline A24 & $\begin{array}{l}\text { The objective of this } \\
\text { research was to } \\
\text { know the factors } \\
\text { those influence the } \\
\text { electricity... }\end{array}$ & $\begin{array}{l}\text { The objective of this } \\
\text { research was to know } \\
\text { the factors that } \\
\text { influence } \\
\text { electricity... }\end{array}$ \\
\hline
\end{tabular}

There was a misformation error of determiner found in that sentence above. It had been found 8 error of omission, 2 error of addition, 0 error of misordering, and 3 error of misformation. 


\subsubsection{Plural}

Tabel 7 The Sample of Grammatical Error of Plural

\begin{tabular}{|c|l|l|}
\hline Code & \multicolumn{1}{|c|}{$\begin{array}{c}\text { Erroneous of } \\
\text { Sentence }\end{array}$} & $\begin{array}{c}\text { The suggestion } \\
\text { of Correct } \\
\text { Sentence }\end{array}$ \\
\hline A24 & $\begin{array}{l}\text { Data collection techniques } \\
\text { in this research are by } \\
\text { submitting } \\
\text { questionnaire(s) to the } \\
\text { respondent(s)... }\end{array}$ & $\begin{array}{l}\text { Data collection } \\
\text { techniques in this } \\
\text { research are by } \\
\text { submitting } \\
\text { questionnaires to } \\
\text { the respondents... }\end{array}$ \\
\hline
\end{tabular}

There was a misformation error of determiner found in that sentence above. It had been found 8 error of omission, 0 error of addition, 1 error of misordering, and 19 error of misformation.

\subsubsection{Noun}

Tabel 8 The Sample of Grammatical Error of Noun

\begin{tabular}{|c|l|l|}
\hline Code & \multicolumn{1}{|c|}{$\begin{array}{c}\text { Erroneous of } \\
\text { Sentence }\end{array}$} & \multicolumn{1}{|c|}{$\begin{array}{c}\text { The suggestion } \\
\text { of Correct } \\
\text { Sentence }\end{array}$} \\
\hline A10 & $\begin{array}{l}\text {...know the influence of } \\
\text { the role of agricultural } \\
\text { extension officers } \\
\text { against empower fertile } \\
\ldots\end{array}$ & $\begin{array}{l}\text { know the } \\
\text { influence of the role } \\
\text { of agricultural } \\
\text { extension officers } \\
\text { against } \\
\text { empowerment } \\
\text { fertile }\end{array}$ \\
\hline
\end{tabular}

There was a misformation error of determiner found in that sentence above. It had been found 28 error of omission, 5 error of addition, 5 error of misordering, and 37 error of misformation.

\subsubsection{Adjective}

Tabel 9 The Sample of Grammatical Error of Adjective

\begin{tabular}{|c|c|c|}
\hline Code & Erroneous of Sentence & $\begin{array}{c}\text { The suggestion } \\
\text { of Correct } \\
\text { Sentence }\end{array}$ \\
\hline A11 & $\begin{array}{l}\text { Oyster mushroom } \\
\text { cultivation is one of the } \\
\text { solutions to meet } \\
\text { consumer demand for the } \\
\text { provision of the oyster } \\
\text { mushroom natural no } \\
\text { longer be able to meet } \\
\text { consumer demand }\end{array}$ & $\begin{array}{l}\text { Oyster mushroom } \\
\text { cultivation is one } \\
\text { of the solutions to } \\
\text { meet consumer } \\
\text { demand for the } \\
\text { provision of the } \\
\text { oyster mushroom } \\
\text { naturally } \\
\text { longer be able to } \\
\text { meet consumer } \\
\text { demand }\end{array}$ \\
\hline
\end{tabular}

There was a misformation error of determiner found in that sentence above. It had been found 17 error of omission, 5 error of addition, four error of misordering, and 7 error of misformation.

\subsubsection{Conjunction}

Tabel 10 The Sample of Grammatical Error of Conjunction

\begin{tabular}{|c|c|c|}
\hline Code & $\begin{array}{c}\text { Erroneous of } \\
\text { Sentence }\end{array}$ & $\begin{array}{c}\text { The suggestion } \\
\text { of Correct } \\
\text { Sentence }\end{array}$ \\
\hline A11 & $\begin{array}{l}\text { whether marketing in } \\
\text { Aji Kuning Village } \\
\text { going efficient, } \\
\text { because (since) Aji } \\
\text { Kuning Village's } \\
\text { farmer disposed to } \\
\text { sell the production to } \\
\text { Tawau }\end{array}$ & $\begin{array}{l}\text { whether marketing } \\
\text { in Aji Kuning } \\
\text { Village going } \\
\text { efficient, since Aji } \\
\text { Kuning Village's } \\
\text { farmer disposed to } \\
\text { sell the production } \\
\text { to Tawau }\end{array}$ \\
\hline
\end{tabular}

There was a misformation error of determiner found in that sentence above. It had been found 24 error of omission, 11 error of addition, 1 error of misordering, and 7 error of misformation. 
3.1.2.10 Gerund

Tabel 12 The Sample of Grammatical Error of Gerund

\begin{tabular}{|c|c|c|}
\hline Code & $\begin{array}{c}\text { Erroneous of } \\
\text { Sentence }\end{array}$ & $\begin{array}{l}\text { The suggestion of } \\
\text { Correct Sentence }\end{array}$ \\
\hline A13 & $\begin{array}{l}\text {...important role in } \\
\text { the production } \\
\text { process to increase } \\
\text { the number of } \\
\text { production or cacao } \\
\text { harvesting... }\end{array}$ & $\begin{array}{l}\text {...important role in } \\
\text { the production } \\
\text { process to increasing } \\
\text { the number of } \\
\text { production or cacao } \\
\text { harvesting... }\end{array}$ \\
\hline
\end{tabular}

There was a misformation error of determiner found in that sentence above. It had been found 20 error of omission, 2 error of addition, 0 error of misordering, and 718error of misformation.

\subsubsection{Adverb}

Tabel 13 The Sample of Grammatical Error of Adverb

\begin{tabular}{|c|l|l|}
\hline Code & \multicolumn{1}{|c|}{$\begin{array}{c}\text { Erroneous of } \\
\text { Sentence }\end{array}$} & $\begin{array}{l}\text { The suggestion of } \\
\text { Correct Sentence }\end{array}$ \\
\hline A13 & $\begin{array}{l}\text {..Tarakan is } \\
\text { influenced } \\
\text { significance toward } \\
\text { production with the } \\
\text { value Fhitung } \\
\text { 67.058. Based on } \\
\text { influenced } \\
\text { the result of the test } \\
\text { (t partial). }\end{array}$ & $\begin{array}{l}\text { significantly toward } \\
\text { production with the } \\
\text { value Fhitung } \\
\text { result of the test }(\mathrm{t} \\
\text { partial). }\end{array}$ \\
\hline
\end{tabular}

There was a misformation error of determiner found in that sentence above. It had been found 83 error of omission, 2 error of addition, 1 error of misordering, and 7 error of misformation.

\subsubsection{Word Ordering}

Tabel 14 The Sample of Grammatical Error of Word Ordering

\begin{tabular}{|c|l|l|}
\hline Code & \multicolumn{1}{|c|}{$\begin{array}{c}\text { Erroneous of } \\
\text { Sentence }\end{array}$} & $\begin{array}{l}\text { The suggestion of } \\
\text { Correct Sentence }\end{array}$ \\
\hline A18 & $\begin{array}{l}\text { Analysis rice } \\
\text { Contribution } \\
\text { Revenue of Rice } \\
\text { Farming } \\
\text { improving }\end{array}$ & $\begin{array}{l}\text { Analysis to } \\
\text { farming revenue } \\
\text { Contribution to } \\
\text { improving }\end{array}$ \\
\hline
\end{tabular}

There was a misordering error of determiner found in that sentence above. It had been found seven error of omission, 0 error of addition, 64 error of misordering, and 1 error of misformation.

\subsubsection{Word Missing}

Tabel 14 The Sample of Grammatical Error of Word Missing

\begin{tabular}{|c|l|l|}
\hline Code & $\begin{array}{c}\text { Erroneous of } \\
\text { Sentence }\end{array}$ & $\begin{array}{c}\text { The suggestion } \\
\text { of Correct } \\
\text { Sentence }\end{array}$ \\
\hline A4 & $\begin{array}{l}\text { descriptive method } \\
\text { economic feasibility } \\
\text { analysis tool, cost } \\
\text { analysis, analysis of } \\
\text { acceptance, }\end{array}$ & $\begin{array}{l}\text { descriptive method } \\
\text { are economic } \\
\text { feasibility analysis } \\
\text { tool, cost analysis, } \\
\text { analysis of } \\
\text { acceptance, }\end{array}$ \\
\hline
\end{tabular}

There was an omission error of determiner found in that sentence above. It had been found 106 error of omission, 0 error of addition, 0 error of misordering, and 0 error of misformation.

\subsubsection{Spelling}

Tabel 15 The Sample of Grammatical Error of Spelling

\begin{tabular}{|c|c|c|}
\hline Code & $\begin{array}{c}\text { Erroneous of } \\
\text { Sentence }\end{array}$ & $\begin{array}{l}\text { The suggestion of } \\
\text { Correct Sentence }\end{array}$ \\
\hline A19 & $\begin{array}{l}\text {...this study is to } \\
\text { determine the } \\
\text { satisfaction of } \\
\text { Farmer In the } \\
\text { counseling aktivity } \\
\text { at Tarakan City }\end{array}$ & $\begin{array}{l}\text {...this study is to } \\
\text { determine the } \\
\text { satisfaction } \\
\text { Farmer In the } \\
\text { counseling activity } \\
\text { at Tarakan City }\end{array}$ \\
\hline
\end{tabular}

There was a misordering error of determiner found in that sentence above. It had been found 94 error of omission, 2 error of addition, 1 error of misordering, and 56 error of misformation. 


\subsubsection{Unnecessary}

Tabel 16 The Sample of Grammatical Error of Unnecessary

\begin{tabular}{|c|c|c|}
\hline Code & $\begin{array}{c}\text { Erroneous of } \\
\text { Sentence }\end{array}$ & $\begin{array}{l}\text { The suggestion of } \\
\text { Correct Sentence }\end{array}$ \\
\hline A19 & $\begin{array}{l}\text { the highest } \\
\text { marketing margins } \\
\text { earned by retailers } \\
\text { marketing agencies } \\
\text { on the marketing } \\
\text { channel III is Rp } \\
30,000 \text {., the farmer's } \\
\text { share of the most } \\
\text { efficient marketing } \\
\text { channel }\end{array}$ & 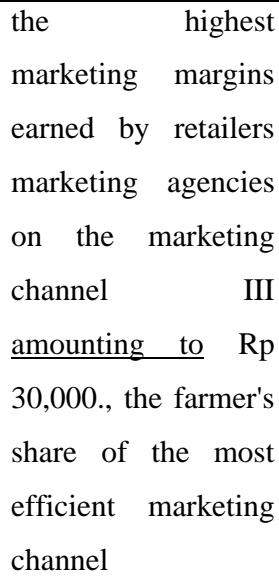 \\
\hline
\end{tabular}

There was an addition error of determiner found in that sentence above. It had been found 0 error of omission, 62 error of addition, 0 error of misordering, and 0 error of misformation.

\subsubsection{Analysis of the Causes of Errors}

The researcher took ten samples of grammatical errors found to be re-analyzed. Those samples were the common errors taken from each category. After the analysis, the researcher classified the errors into four categories. The taxonomy of error was used to analyze the sources of errors was a comparative analysis taxonomy proposed by Dulay [6], [7]. The samples were showed as follows.

\subsubsection{Developmental Errors}

According to Dulay [6], developmental occurs when students learn and apply their target language like their first language that means the students already can adapt to their target language, but sometimes they do not notice their target language grammar. For example, "Tarakan City is a city island surrounded by the oceans ..." These errors commonly happen in the sentence produced by students that learn English as their second and foreign language. This condition occurs when the students try to overgeneralize in using verb to write a sentence in English.

\subsubsection{Interlingual Errors}

Ellis [8] [9] interlingual can occur when students construct a linguistic system in students' native language, which is different from their target language linguistic system. That means students exactly arrange sentences in their native language pattern and rules. At this point, the researcher described the sample sentence that occurred because of the interlingual errors.

\subsubsection{Ambiguous Errors}

Dulay [6], ambiguous is a source of errors that can be classified as developmental and interlingual because these sources of error reflect the student's knowledge of the target language and the influence of students' native language.

\subsubsection{Other Errors}

Dulay [6] other errors are the errors that do not fit either in developmental or interlingual. The kind of errors made by others is commonly caused by students who arrange a sentence structure that does not reflect developmental or interlingual. It means the students create their language as the uniqueness. They were categorized to the students' unique language spontaneously, and sometimes it did not have any meaning. So, they were considered as other errors.

\section{CONCLUSION}

The findings and discussion in the previous chapter were summarized to accomplish the objective of the study. There were 1079 total errors found in the abstracts of the Borneo university Tarakan students. Based on the data analysis, the researcher concluded that there were eighteen kinds of grammatical errors found in the 225 thesis abstracts of Borneo University Tarakan students. They were the errors in the four categories of omission, addition, misordering, and misformation. [6] The eighteen subcategories are tense, verb, verb be, preposition, conjunction, articles, word missing, spelling, word order, adjective, noun, gerund, auxiliary, plural, singular, unnecessary, determiner, and adverb. Most of the grammatical errors were caused by spelling and word missing.

The researcher can also conclude that when the types of errors within the percentages of types of errors there were $52,1 \%$ errors of omission, $13,3 \%$ errors of addition, $8 \%$ errors of misordering, and $26,6 \%$ errors of misformation.

Developmental had occurred when the students likely wrote the English sentence by translating it in Indonesian pattern without notice of English grammar. While the interlingual error occurred when the students wrote English in Indonesian pattern and rules, it was similar to how they said in their native language, and the sentence they wrote did not seem like an English sentence pattern at all. Meanwhile, ambiguous occurred as the combination of developmental error and interlingual, when in the sentence they committed those errors simultaneously, and others occurred when it was not included in those three categories. When the students created their language spontaneously and 
sometimes, it did not have any meaning, or the students could not translate what they had written. From those errors and failures, the students could learn and practice better to adjust their weaknesses in learning their target language (English).

\section{REFERENCES}

[1] A. S. Hornby, Oxford Advanced Learners' Dictionary, 6th edition. New York: Oxford University Press, 2000.

[2] D. Holtom and E. Fisher, Enjoy Writing Your Science Thesis or Dissertation. London: Imperial College Press., 1999.

[3] E. Fisher and R. Thompson, Enjoy Writing Your Science Thesis or Dissertation, Second ed. London: Imperial College Press., 2014.

[4] S. P. Corder, Error Analysis and Interlanguage. Oxford: Oxford University Press., 1981.

[5] P. Lennon, "Contrastive Analysis, Error Analysis, Interlanguage," in Bielefeld Introduction to Applied Linguistic. A Course B, Bielefeld: Aisthesis Verlag, 2008.

[6] H. C. Dulay, M. K. B, and S. D. K, Language Two. Oxford: Oxford University Press, 1982.

[7] M. Zhang, "Error Analysis and Interlanguage," Focus (Madison)., vol. 1, no. 1, pp. 85-93, 2011.

[8] R. Ellis, Second Language Acquisition. Oxford: Oxford University Press, 1997.

[9] J. C. Richards, Error Analysis: Perspectives on Second Language Acquisition. Routledge, 2015. 